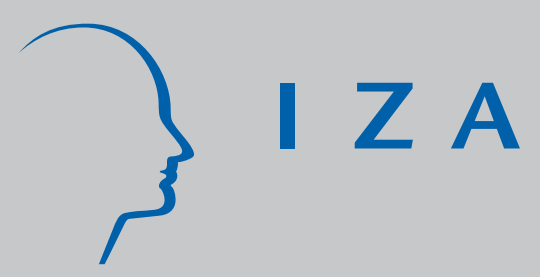

IZA DP No. 10

Income and Employment Effects of Health Shocks

- A Test Case for the German Welfare State

Regina T. Riphahn

J une 1998 


\title{
INCOME AND EMPLOYMENT EFFECTS OF HEALTH SHOCKS - A TEST FOR THE GERMAN WELFARE STATE
}

\author{
Regina T. Riphahn
}

\author{
Discussion Paper No. 10 \\ June 1998 \\ Forthcoming in: \\ Journal of Population Economics, 3/99
}

\author{
IZA \\ P.O. Box 7240 \\ D-53072 Bonn \\ Germany \\ Tel: +49-228-3894-201 \\ Fax: +49-228-3894-210 \\ Email: iza@iza.org
}

\begin{abstract}
This Discussion Paper is issued within the framework of IZA's research area The Welfare State and Labor Markets. Any opinions expressed here are those of the author(s) and not those of the institute. Research disseminated by IZA may include views on policy, but the institute itself takes no institutional policy positions.
\end{abstract}

The Institute for the Study of Labor (IZA) in Bonn is a local and virtual international research center and a place of communication between science, politics and business. IZA is an independent, nonprofit limited liability company (Gesellschaft mit beschränkter Haftung) supported by the Deutsche Post AG. The center is associated with the University of Bonn and offers a stimulating research environment through its research networks, research support, and visitors and doctoral programs. IZA engages in (i) original and internationally competitive research in all fields of labor economics, (ii) development of policy concepts, and (iii) dissemination of research results and concepts to the interested public. The current research program deals with (1) mobility and flexibility of labor markets, (2) internationalization of labor markets and European integration, (3) the welfare state and labor markets, (4) labor markets in transition, (5) the future of work, and (6) general labor economics.

IZA Discussion Papers often represent preliminary work and are circulated to encourage discussion. Citation of such a paper should account for its provisional character. 
IZA Discussion Paper No. 10

June 1998

\section{ABSTRACT}

Income and Employment Effects of Health Shocks - A Test Case for the German Welfare State*

Using data from the first eleven waves of the German Socio-Economic Panel this study investigates the dynamic effects of health shocks on employment and economic wellbeing of older workers. A health shock trebles the probability of leaving the labor force and almost doubles the unemployment risk. The financial effects of health shocks are small on average and those individuals with the highest remaining earnings potential are least affected by the health shock. Welfare state instruments support the poorest section of the population but do not succeed in neutralizing the effects of a health shock for these groups.

JEL Classification: I10, J21, J28, J26

Keywords: health, labor force participation, earnings, welfare state

Regina T. Riphahn

SELAPO - Universität München

Ludwigstr. 28 RG

D - 80359 München

Germany

Tel.: +49-89-2180-2128

Fax: +49-89-336392

email: Regina.riphahn@selapo.vwl.uni-muenchen.de

* The author thanks K. F. Zimmermann, R. Rotte and participants of the GSOEP 1996

Conference in Potsdam for helpful comments on earlier drafts of the paper. 


\section{Introduction}

While the debate on the future of the welfare state circles around questions of its aggregate, macroeconomic costs (see e.g. Morgan, 1995, Dilnot, 1995, or Orszag and Snower, 1997), its effectiveness and microeconomic benefits have to a large extent been left unexamined. One of the welfare state's purposes is to insure individuals against extreme and unforeseen income loss and to facilitate thereby investments that risk averse individuals would not otherwise take (Sinn, 1995, Berthold and Fehn, 1997). The objective of this study is to provide evidence on whether the German welfare state succeeds in reaching this insurance goal. As an example of the type of event that individuals should be insured against, this study looks at health shocks and investigates their dynamic effects on the employment and income position of older workers.

Health might be a major factor behind the declining labor force participation (LFP) of older workers, which strains not only the German social insurance system: Between 1984 and 1993 LFP fell by 9.5 (14.2) percent for workers aged 55-59 (60-64). Compared to 1980 the LFP of those aged 60-64 declined by even 32 percent. Also, older workers (above age 40) make up more than 70 percent of the longterm unemployed. Instead of earning an income through gainful employment, these workers receive benefits under early retirement, unemployment, or disability retirement schemes. Since these modes of labor force exit frequently are prompted by a decline in health ${ }^{1}$ it is worthwhile to study the effect of health deterioration on older workers' employment status.

A decline in potential labor incomes may indirectly cause workers' labor force exit and should therefore be considered in a complete description of employment responses to health shocks. The earnings consequences of a health deterioration for previously employed individuals provide a measure for the degree of income security furnished by the welfare state. Such an empirical evaluation of the functioning of the German welfare state is timely as the German government continues to cut back the protective instruments of the social insurance system.

Health shocks are defined as sudden deteriorations in a person's health that might be brought about by accidents or by diseases. This paper concentrates on sudden health changes to 
connect reliably changes in health with employment and income responses, and in order to distinguish the effects of health from those of other environmental factors. The study investigates the evidence on health shocks and their labor market effects as it presents itself in the first eleven waves of the German Socioeconomic Panel (1984-1994).

The central findings are that health shocks have a clear impact on subsequent labor force participation. Suffering a health shock increases the probability of dropping out of the labor force by 200 percent and drives up the unemployment risk by 90 percent. The negative effects of health shocks on household income and individual earnings are visible, particularly in the period following the event. Women are most strongly affected by a drop in labor earnings, while households in which the health-shocked individuals left employment suffer the most severe decline in equivalent household income. These households are addressed by goverment benefit programs, yet their effects do not balance the health shock related losses.

The paper proceeds as follows: Section 2 surveys the literature and introduces the relevant aspects of the German welfare state. The frequency and correlates of health shocks are described in section 3. Section 4 evaluates their effects on labor force participation, and section 5 discusses the income effects. Section 6 summarizes and concludes.

\section{Background}

\section{The Literature}

The literature on the employment and earnings effects of a health shock consists of three groups: the studies on the interdependencies between health and unemployment, ${ }^{2}$ the empirical retirement literature which finds consistently that health is an important determinant of LFP, ${ }^{3}$ and finally the studies that look at labor market effects of the onset of health impairments.

Within the last group Burkhauser, Butler, and Kim (1995) investigate the role of employer provided accommodation for the subsequent job duration of individuals experiencing a health impairment. They find that employer accommodation can significantly reduce the risk of leaving employment. Daly and Bound (1995) look at the labor market consequences of health 
impairments. They regress the employment responses to a health shock, such as remaining with an employer, changing employers, or leaving the labor force, on individual and employer characteristics and focus on workers who continued to work after a health shock. These authors find that employers can reduce job turnover by accommodating workers who suffer a health impairment.

Baldwin, Zeager and Flacco (1994), Haveman and Wolfe (1990), and Burkhauser and Daly $(1994,1995)$ concentrate on the financial consequences of suffering a health shock. Baldwin et al. (1994) evaluate the gender-specific wage losses brought about by existing health limitations. Haveman and Wolfe (1990) study the development of earnings and family income of the disabled between 1962 and 1984. The most detailed account of the employment and income consequences of a disability is provided by Burkhauser and Daly (1995). They find that whereas the onset of a disability does have an effect on earnings and subsequent employment, household size adjusted income does not fall substantially. In their 1994 study these authors compare the consequences of disability for German and U.S. workers and find that disability status has virtually no impact on household economic well-being or on earnings for the German sample.

\section{$\underline{\text { Institutions of the German Welfare State }}$}

The welfare state institutions concerned with health and the health-related loss of earnings capacity are numerous and overlap in competencies. Given that the empirical analysis below does not focus on any particular institution or policy instrument this section provides a brief general survey of relevant institutions. ${ }^{4}$

If an employed worker falls sick and cannot show up for work the person is covered by sickleave benefits. Prior to 1997 employers had to continue paying 100 percent of regular earnings for the first six weeks that a person was unable to work. If the individual cannot return to work after six weeks, the health insurance starts paying 'sickness benefits' amounting to 80 percent of last net earnings for up to 78 weeks. After this period the retirement insurance takes over and finances further medical treatment and/or disability benefits which amount to about 60 
percent of last net earnings.

For almost all blue and white collar workers the public health insurance covers almost 100 percent of medical expenses, with slight increases in required copayments since the mid eighties. For the self-employed or those individuals exceeding the earnings limit, health insurance is not mandatory and they can opt for no or private insurance coverage.

Individuals who become unemployed are eligible for benefits from the unemployment insurance. First they can receive unemployment benefits which, depending on whether there are dependent children in the recipient's household, run at replacement ratios of 60 or 67 percent of last net income. The benefit duration varies by the age of the individual and by past contribution periods. For persons who have contributed for at least two years unemployment benefits run at least for 12 months. When unemployment benefits expire or are not available due to very short prior contribution periods, means-tested unemployment aid is available. Unemployment aid runs indefinitely and replaces 53 or 57 percent of last net income, again depending on whether dependent children live in the household. For some unemployed this aid payment is not sufficient to cover subsistence. In these cases means tested social assistance benefits are available to bring monthly payments up to a given minimum level.

Finally, the accident insurance may provide benefits to individuals who suffer a health shock due to a work-related accident. The accident insurance provides medical treatment to enable the individual to return to work. It pays benefits during vocational rehabilitation programs, and for those who are out of the labor force after the accident at 80 percent of last net income. For persons who remain disabled the accident insurance covers disability benefits.

The German "layoff protection legislation" does not prohibit laying off individuals due to declining health. However, it mandates advance notice periods which vary based on tenure, age, and type of employment (i.e. full-time or part-time). In addition to federal law the bargained contracts between unions and employers determine industry-specific conditions for lawful layoff.

Thus, various institutions of the welfare state may be involved with and interact in response to a health problem. To sum up, health care is typically fully covered by the health 
insurance and earnings replacements are available from either the employer, the health, unemployment, retirement, or accident insurance, depending on individual circumstances. The replacement ratios vary between 100 percent during the first six weeks as provided by the employer and about 50 percent means-tested benefits available from the unemployment insurance through unemployment aid.

While most financial benefits are thus determined by the prior amount of a person's earnings, the precise individual circumstances and the nature of the health problem can differ substantially. This renders general statements as to the level and duration of the welfare state's support impossible. In addition, this overview shows that numerous detailed questions would have to be asked of survey respondents affected by health problems in order to determine the nature of the welfare state's response. If anything can be hypothesized based on the above description it would be that those individuals who are only marginally integrated into the institutions of labor market and welfare state will be most affected by the financial consequences of health shocks. Benefits typically depend on prior earnings, while employment protection and benefit eligibility are correlated to tenure and prior labor force participation experience.

\section{Dataset and Definition of Health Shocks}

This study uses data from the first eleven waves of the German Socio-Economic Panel (GSOEP). Given our interest in the health shock effects for older workers the sample includes full-time employed West-German and foreign individuals aged 40 to $59 .{ }^{5}$ We drop persons above age 59 since they may be eligible for retirement programs. After omitting all observations with missing values for health satisfaction or other explanatory variables we obtain a sample of 19,509 annual observations of individuals in full-time employment.

The ideal measure for a health shock combines information on the type of health problem with indicators of its suddenness, severity, and duration. Only few datasets provide information with the necessary detail. While the GSOEP is not among them it contains several health-related questions which permit the definition as well as the validation of a health shock measure. In each 
survey respondents were asked to evaluate their health satisfaction on a scale between zero and ten. Using the answers to this question health shocks are defined as a sudden drop in health satisfaction by at least five points on the scale from zero to ten. ${ }^{6}$ Given that such a large change in health satisfaction occurs within just one period and since endogenously determined health deteriorations can be expected to follow a more continuous development, the event may well be regarded as an exogenous shock. Potential reasons for such a sharp drop in health satisfaction include the health consequences of an accident, the onset of illness or of a physical handicap. One of the drawbacks of the health shock measure is that it does not contain information on the nature of the underlying health problem. Given that the health shock measure only describes a one time deterioration in health it does not permit one to differentiate between permanent and short term health problems.

Figure 1 presents the distribution of changes in health satisfaction between consecutive surveys and depicts the health changes separately for men and women. Since answers between 0 and 10 are possible, the interperiod differences range from -10 to 10 . The fraction of individuals who experience no or only minor changes in health satisfaction from period to period is sizable. Women tend to indicate slightly larger changes in health satisfaction than men. The differences across age groups are small but a larger tendency for health deterioration exists in the oldest group. In comparison to German workers foreign respondents are more heavily represented in both tails of the difference distribution. An evaluation of the frequency distribution of health changes across survey years shows that the propensity to experience large deviations in health satisfaction decreases over time. ${ }^{7}$

The information contained in the GSOEP allows one to validate the health shock measure by comparing it to changes in other health indicators. Since health satisfaction is the only indicator that is available for the entire survey period, all comparisons are necessarily based on subsamples of survey years. Table 1 describes the correlation of the health shock measure with other health indicators. The column entitled 'Factor' describes how much more likely individuals who suffered a health shock are to report an indicator of deteriorated or poor health in 
comparison to the population that did not experience a health shock. The population which indicated a health shock is about three times as likely to report a new health limitation, a health deterioration, or long periods of sick leave compared to the population that did not indicate a health shock. Each of the alternative health measures provides evidence of the substance and thus of the usefulness of the health shock measure.

Additionally, studies by Nagi (1969), Maddox and Douglas (1973), LaRue et al. (1979), and Ferraro (1980) are cited by Sammartino (1987), and find that self-reported health status is highly correlated with medically determined health status. Research by Mossey and Shapiro (1982) even found that self-reported poor health was a slightly better predictor of subsequent mortality than objectively determined health status. Wagner (1991) shows a close correlation of subjective health satisfaction with objective and subjective life-expectancy, and Burkhauser and Daly (1994) stress the high degree of correlation between the health satisfaction measure and other indicators of health limitations.

\section{Employment Effects}

For an exploratory analysis of workers' responses to a health shock four labor force states were coded: Full-time employment, part-time employment, unemployment, and out of the labor force (OLF) the latter including irregular and minor employment. Table 2 describes the distribution of the sample across states. It distinguishes the full sample from those individuals who suffered a health shock and provides information on transitions in subsequent years. The sample sizes fall over time due to right censoring in later waves and due in part to missing information. The table shows that the probability of leaving full-time employment increases after experiencing a health shock. Thirteen percent of those whose health satisfaction dropped suddenly were no longer full-time employed in the next period (t). This fraction grows to 17 (21) percent after another (two) year(s). The majority of these individuals leaves the labor force altogether. From among those who remained full-time employed after one year about ten percent gave up full-time employment in the second year after a health shock (in period $t+1$ ). Conversely, 
about one quarter of those who left full-time employment immediately after experiencing a health shock returned in the next year.

A comparison of transition probabilities after a health shock by exogenous characteristics yields interesting insights (see Table 3): Women appear to be much more likely to drop out of full-time employment after a health shock than men. Close to 80 percent of all transitions into part-time employment are completed by women who make up just 24 percent of the sample. The differences by nationality appear to be minor, with the only exception, that foreigners are more likely to end up unemployed than Germans. A possible explanation lies in the lower average tenure observed for guest-workers as compared to German natives. Given the employment protection regulations discussed above, tenure serves as a protection mechanism against layoff. The distribution of transitions across age groups follows expections: The fraction of individuals remaining in full-time employment falls with age, and in parallel the fraction that drops out of the labor force increases. The only exception is the oldest age group, where we find a very high probability of unemployment. This corresponds closely to the actual labor market situation, where the unemployment rates for the 55-59 age group exceed those of all other age groups.

\section{Multivariate Analysis}

In order to investigate the relative impact of a health shock on labor market transitions a multinomial logit model is estimated for the set of four discrete outcomes. The explanatory variables are defined in Table 4, which also presents descriptive statistics. ${ }^{8}$ A comparison of group means indicates that those who experience a health shock have on average less schooling, lower incomes, they are more likely to work in manufacturing or in the construction industry and are less likely to be office workers, highly skilled managers, or to be employed in the public sector.

Following Booth et al. (1996) the estimation equation controls for those measures that determine the labor force decisions of individuals: demographic and human capital measures, characteristics of the current employment and labor demand effects. Among the demographic 
measures age, sex, nationality, and marital status are considered. As indicators of human capital years of schooling, the level of training required for the job, an indicator for whether the person suffers a chronic disease, and net real monthly income are included. Since individuals' labor market earnings are possibly endogenous to labor force transitions I use a measure of predicted labor market income based on a standard human capital regression. The group of employment characteristics controls for firm size, for whether the person works as an office worker, in manufacturing, and whether the job is in the public sector, in the construction, retailing, or electrical and precision engineering industry. ${ }^{9}$ To control for macroeconomic and labor demand effects the annual national unemployment rates as well as a set of year and state fixed effects are considered.

The estimation results are presented in Table 5. The coefficients describe the impact of the variables on the log odds of a transition from full-time employment into the states of parttime employment, unemployment or the out of the labor force state relative to remaining in fulltime employment. Noticeable are the large coefficients for females in the transition to part-time employment, of the public sector in the transition to unemployment, and of the health shock in the transition out of the labor force. We find highly significant effects of suffering a health shock on all three transitions. The state and period fixed effects controls significantly improve the fit of the model.

To evaluate the relative impact of the covariates simulation experiments were performed. These experiments are based on predicting average transition probabilities for the entire sample. Procedures and results are summarized in Table 6. The figures indicate a sizeable impact of health shocks on transition probabilities: Experiencing a health shock reduces the probability of remaining full-time employed by about 6 percent, it increases the probability of entering part-time employment by about 60 percent, the probability of unemployment by 84 percent and of dropping out of the labor force by about 200 percent. The impact of a health shock on the propensity to transit into part-time employment is small. Here only being female plays an important role: It increases the average probability of part-time employment by 220 percent over 
the sample average.

Out of all the characteristics controlled for, experiencing a health shock appears to be the most important determinant of dropping out of the labor force. Important determinants of transitions into unemployment are the female and public sector indicators, as well as aggregate unemployment. Given that employment in the public sector offers a high degree of job security, the negative effect of public sector on the unemployment risk adheres to expectations.

At first sight it seems surprising that high predicted incomes increase the unemployment risk and reduce the probability of remaining employed. Based on the description of the welfare state above we know that individuals with high earnings are those with the highest benefits under the unemployment and disability system as well. Given that we are looking at older workers, a plausible explanation for the positive income effect on the unemployment risk is to interpret predicted incomes as a proxy for unemployment benefits, which in reality are calculated as a fraction of last net earnings. As has been shown in numerous studies of the incentive effects of unemployment benefits (see e.g. Steiner, 1997), elderly workers with higher unemployment benefits (and a longer benefit duration) might be able to better secure their financial needs through unemployment benefits and thus may be more likely to become and remain unemployed than those who cannot count on sufficient funding through the unemployment insurance. In addition, voluntary unemployment is not infrequent in German preretirement programs, where workers supplement unemployment benefits by payments through their last employer (see Riphahn, 1997). Also, those who have earned high incomes are likely to have accumulated (e.g. housing) wealth and assets over the life cycle and can better afford unemployment than those who still have to worry about the monthly rent payments.

Confirming the findings of the large literature on the effects of firm size on job duration and turnover (for recent surveys see Even and MacPherson, 1996, or Groothuis, 1994) we find a reduced probability of remaining in full-time employment for workers in small establishments. Working in a small firm reduces the probability of continued full-time employment by about 2 percent and increases the risk of unemployment by 56 percent. Working in very large 
establishments increases the probability of continued full-time employment slightly and reduces the risk of unemployment by 18 percent below the sample average.

\section{Income Effects}

After the clear employment effects of health shocks have been established above, this section evaluates the income dynamics of both individual labor earnings and household incomes for individuals suffering a health shock. While earnings measure the financial consequences of a health shock for those who remain employed, we just saw that health shocks do not allow everybody to stay employed. Therefore we choose household incomes as a measure of financial well-being, which also reflects the impact of state transfers. To take account of economies of scale in household consumption related to the size and age-structure of a household, household income is customarily adjusted using equivalence scales. Two different equivalence scales are applied here to provide a control for the robustness of the results: The first uses the weights inherent in the German welfare system, ${ }^{10}$ and the second adjusts by the square root of the number of household members (cf. Buhmann et al., 1988). A descriptive analysis of earnings and household incomes is presented first and a multivariate study of the determinants of income changes follows.

\section{Descriptive Analysis of Earnings and Household Incomes}

Two descriptive approaches are taken to evaluate the financial effects of health shocks: First, labor earnings and household incomes of individuals were compared over time between those who did and those who did not suffer a health shock. The results are presented in Table 7. ${ }^{11}$ The figures for the full sample in panel (a) show that labor earnings and household incomes of those individuals who subsequently suffer a health shock are below those of the "healthy" population even before the health shock takes place. After the health shock occurred between periods $\mathrm{t}-1$ and $\mathrm{t}$, the income ratios decline modestly across all measures: individuals suffering a health shock earn 87.2 percent of the labor incomes of the "healthy" population in the year after 
the shock $(t+1)$, instead of 88.3 prior to the shock. Household income ratios decrease from about 92 percent in period t to about 89 percent in period $t+1$.

When the sample is broken down by nationality and gender (Table 7 (b)), we find that the different subsamples undergo quite varied developments in labor earnings. While the ratios for German and foreign men decline by less than two percentage points after a health shock and increase beyond original levels again in period $t+3$, the ratios for German and foreign women show larger and somewhat more permanent effects. ${ }^{12}$ The last two columns of panel (b) show evaluated cum grano salis given the small number of observations - that those taking up parttime employment after the health shock suffer a larger relative decline in earnings than full-time workers. Keeping in mind that more than 90 percent of part-time workers in Germany are female this confirms the above findings.

Table 7(c) describes the development of household equivalent income ratios across subsamples. It appears that the income differences for households with and without 'healthshocked' individuals even before the health shock are smaller for foreign compared to German households. While foreign households have about equal equivalent incomes independent of health status German households later suffering a health shock make no more than 95 percent of the healthy control group. As in panel (a) equivalent income ratios decline generally in period $t+1$ with a somewhat larger percentage point drop for German than for foreign households. While the two measures of equivalent income generate income ratios of different magnitude, they generally indicate developments in the same direction. When evaluating household incomes by employment status (see bottom panel of Table 7) we find that only the household incomes of households with full-time employed individuals suffer a clear drop in incomes in period $t+1$. Yet, as long as the affected individuals are still full-time employed, these housholds maintain income ratios above the average for the full sample (i.e. for period t ratios of .941 and .934 in Table 7 (c) compared to .923 and .917 in Table 7 (a)). When formerly full-time employed individuals first become unemployed or drop out of the labor force in period $t$ (see the last four columns of Table 7 (c)), their equivalent household incomes decline relative to the households of healthy individuals who 
become unemployed or drop out of the labor force in the same period.

The figures in parentheses present income ratios for subsamples defined by their employment status in period $\mathrm{t}+1$ in order to help disentangle the changes in income ratios in subsequent periods (being full-time employed in period t does not imply employment in subsequent periods). Not surprisingly we find that income ratios of 0.913 and 0.916 in period $t+1$ for the then full-time employed exceed the averages in panel (a) (.896 and .890) as well as those of the subsample which is full-time employed in the preceding period (0.904 and 0.900). Yet, a modest fall in income ratios after the health shock occurs for this subsample as well. The decline in household incomes of the formerly full-time employed in subsequent periods can be explained by an increasing fraction of labor force dropouts (see Table 2).

The opposite effect materializes for the unemployed: In period $t+1$ those unemployed in $\mathrm{t}+1$ (figures in parentheses) have income ratios (.984 and .909) that are below those of the individuals who were unemployed in period t (.997 and .986), since the latter may have increased their incomes by reentering employment by period $t+1$. The effect of a health shock on the relative household income of the unemployed and those out of the labor force is visible mostly in period t. The incomes of the unemployed increase in later periods possibly due to reentering the labor market. But since the number of observations who are unemployed or out of the labor force is small the observed effects may not be reliable.

The second descriptive approach investigates the effect of health shocks on income growth over time (see Table 8). The results for the full sample in panel (a) show that the increase in monthly labor earnings dropped from 5.6 percent in the year of the health shock to only 3.8 percent over the same base year in the following year $(\mathrm{t}+1)$. A smaller decline from 4.8 to 4.0 percent is observed for the household income measure. The decline occurs only in the period subsequent to the health shock and is reversed in the next year when income growth increases again. The income paths of individuals suffering a health shock deviate from the consistently positive income growth trend for the "healthy" control population (figures in parentheses). 
The evidence from the subsamples by gender and nationality in panel (b) shows some variation in the earnings developments: The only subgroup that appears to suffer a decline in earnings are foreign men which, however, is due only to a surprisingly strong growth measure for period t. Earnings for the German subsamples continue to grow even after a health shock and the growth rate in the incomes of foreign women is negative already in the year of the health shock. On average full-time employed workers (as of period t) seem to suffer a decline in earnings between periods $\mathrm{t}$ and $\mathrm{t}+1 .{ }^{13}$ The figures for part-time workers indicate a large drop in earnings in the year of the health shock when they just left full-time employment and a catching up effect later. However, due to the small sample size these effects may not be reliable.

For a different perspective Table 9 compares earnings changes for healthy and nonhealthy subsamples over various subsequent periods. Based particularly on the first two panels it is clear that the earnings developments of German and foreign women are most affected by health shocks while the income growth rates of either male subsample hardly fall behind those of the healthy subsample at all. The differences by gender reflect the high probability for women to leave fulltime employment after a health shock shown in section 4 above. The somewhat different results in the last panel, describing the income changes in the third year after the health shock are likely to be connected to health related changes in the samples: only the healthier workers remain employed continuously while those most severely hit by health shocks can be expected to drop out of the sample.

Finally, the last panel of Table 8 describes the changes in equivalent household incomes over time. Generally the "healthy" population enjoys continuous positive growth rates (figures in parentheses). The exception of an income decline between periods $\mathrm{t}-1$ and $\mathrm{t}$ for the "healthy" unemployed and out of the labor force subsamples is related to their leaving the labor force after period t-1. Upon suffering a health shock German workers and those full-time employed as of period $t$ experience a decline in household incomes in period $t+1$. However, if we condition on continuous full-time employment through period $t+1$ the decline in household incomes between periods $t$ and $t+1$ completely disappears, indicating that the decline in the average may be caused 
by those formerly employed individuals who after suffering a health shock drop out of the labor force. The equivalent household incomes of foreign workers appear to remain unaffected by the health shock and the incomes of the unemployed and those dropping out of the labor force as of period t do not decline further after they have left employment. Only for household incomes of part-time workers do we observe a decline in growth rates two years after the health shock, which does not correspond to the earnings development for this group (Table 8(b)), and may well be a statistical artefact connected to the small number of observations.

The descriptive analyses have shown that individuals suffering a health shock are already worse off financially before the health problems occur. The comparison with "healthy" persons as well as the description of income developments over time, suggest that the effects of a health shock on labor earnings and household incomes are most clearly visible in in the year following the health shock. Particularly affected by the decline in labor earnings are German and foreign women while household incomes show a smaller decline for the foreign sample and for those households where the health-shocked individuals remain full-time employed. Overall the effects appear to be short lived as incomes and earnings increase again in the second year after the health shock.

\section{Multivariate Analysis: Individual Earnings}

Health shocks appear to have small average effects on individual labor earnings and seem to affect mostly the female subsamples. This section investigates which worker and employment characteristics are correlated with declines vs. continued increases in labor earnings for workers suffering a health shock. To do this we define our variable of interst as the percentage change in earnings between the periods prior to $(\mathrm{t}-1)$ and after the health shocks $(\mathrm{t}+1)$. This definition is useful because the largest earnings effects were observed in the period subsequent to the shock $(\mathrm{t}+1)$. The analysis considers only those observations for which income measures are observed in both periods and for which all explanatory variables in the regressions are observed. A first description of the distribution of the dependent variable is presented in Table 10(a). The median 
full-time worker has nearly constant earnings in the two periods (an increase of 0.1 percent). Among the foreign subsamples we find more workers with declining earnings, while the median German employee enjoyed an increase in earnings between the periods $t-1$ and $t+1$.

The last four rows of Table 10(a) split the sample into those observations with earnings above and below the mean, in the two periods surrounding our measure of earnings change. When comparing the change in gross real earnings between the top and bottom income earners as distinguished based on earnings in the period prior to the health shock we find only minor differences: Both groups have about stagnating incomes at the median. In contrast, the income growth experience differs more strongly for the top and bottom earners as distinguished based on earnings in period $t+1$ : For these two groups we find differences in earnings growth at the magnitude of 7 percentage points evaluated at the median of either group.

Since only those workers who are least affected by a health shock are likely to continue full-time employment, the estimation is performed using a simultaneously estimated Heckman correction model to control for potential sample selection bias. The employment model in section 4 showed significant impacts of aggregate unemployment and of a positive time trend on the unemployment risk. Therefore these two variables are included in the selection and omitted from the earnings growth equation to help identification. In addition, age is described by four categories in the selection equation and is modelled linearly in the earnings equation. The purpose of the regression analyses on earnings and household incomes is not to determine structural or behavioral parameters, but to add another perspective to the description presented above. Table 11 presents descriptive statistics on the relevant sample, and Table 12 shows the estimation results.

In the description of the welfare state in section 2 we hypothesized that individuals who are only marginally integrated in the institutions of the labor market are likely to suffer the most severe consequences of health shocks on employment and income. The labor earnings effects investigated here condition on full-time employment in the period before (t-1) and after the health shock $(\mathrm{t}+1)$ and thus are restricted to those workers who are fully integrated in the labor 
market. We can see from the highly significant selection effect that this sample is not representative for all individuals suffering a health shock. The selection equation controls for whether an individual suffering a health shock remains full-time employed. We find a number of statistically significant determinants, which indicate that chances to remain in full-time employment increase when the person is young, when health satisfaction after the health shock stays high (i.e. if the health shock is either a shortterm phenomenon or not too severe), when the person does not work in a small firm, and when the overall unemployment rate is low. Also, the risk of leaving employment increases over time. These effects confirm the findings of section 4 above. $^{14}$

The equation for earnings growth controls for variables typically considered relevant in earnings equations. Among them are demographic characteristics such as age, nationality and sex, and it also conditions on health satisfaction after the health shock, on human capital measures, and on firm size. Occupation and industry indicators, as well as more detailed measures of the workers' human capital were controlled for in prior estimations but since they did not add to the explanatory power they were omitted in the final specification. The estimation results indicate that high income growth within the period of observation is determined by good health, young age, long tenure and more hours of work. These effects are statistically significant. Being of foreign nationality or female on average reduces earnings growth, but not at a statistically significant rate. Similarly, we observe higher earnings growth for employees of large firms than for those of small firms, and for those with more years of schooling. These effects are measured imprecisely and are not statistically significant. The results show that it is not a certain subgroup of the population, in a particular type of employment or industry, which suffers the least or highest earnings loss after a health shock. We cannot even distinguish significant effects for the nationality and gender groups that were evaluated in the preceding section. Instead it appears that those individuals who are not too old, enjoy good health, who work long hours, and have been with the company for a number of years are likely to suffer the least shock to their labor earnings. This confirms the descriptive statistics from Table 10 and shows that individuals 
with the highest earnings potential also suffer the smallest loss in earnings, or vice versa, those who can least afford it, take the biggest hit.

This direct earnings effect is relevant only for those individuals who remain employed. Since for individuals who drop out of work equivalent household income is the more appropriate measure of the economic effects of a health shock, we investigate the determinants of changes in equivalent household income next.

\section{Multivariate Analysis: Household Income}

The growth rates in equivalent household income between the periods before (t-1) and after the health shock $(\mathrm{t}+1)$ are described in Table 10(b). Surprisingly, the smallest median growth rate is observed for the subsample of German men while German women appear to have suffered the least household income loss after a health shock. Dividing the sample by employment status in period $t+1$ we find vast differences in growth rates between the unemployed for whom even the 90th percentile experiences a fall in incomes and those who stay in employment and enjoy median growth rates above the average.

In a next step we investigate the impact of three groups of potential determinants of household income using a standard linear regression model, which separates the effects of three groups of variables relevant to the development of household incomes. The first describes the household member suffering the health shock and this individuals' earnings capacity, the second group describes the labor market involvement of other household members, and finally three measures indicate whether the household receives benefits from the government, such as unemployment support, social assistance and a rent support. The estimation results are presented in Table 13, for descriptive statistics see Table 11.

The characteristics of the health impaired individual do have a significant impact on overall household well-being. From among the four most important determinants of individual earnings change after a health shock (see Table 12) only the hours and health satisfaction measures are statistically significant and have positive effects on household equivalent income. 
We find that foreign nationality is (insignificantly) associated with lower household income growth. If the health impaired household member is female this implies a surprising positive and significant effect of about eight percentage points on income growth. This might be an indication that in comparison to men, women did not contribute a major portion to the household budget before they suffered the health shock. The household structure effects are as expected, as a larger number of full-time or part-time earners increases household equivalent income. This does not prove that household members substitute their labor market participation for each other, but it shows that equivalent household income is much less likely to fall and more robust to health shocks in multiple-earner households. It is surprising that having more children is correlated with a stronger growth in household equivalent income, but this effect can be rationalized by two correlation patterns: First the number of children is correlated with the employment status of the health-shocked household member. The probability of full- or part-time employment in period t+1 amounts to 95 percent if children are in the household and 89 percent otherwise. In addition, households with children are younger than the average which again is correlated with higher earnings. The control variables for the employment status of the health-shocked household member in period $t+1$ indicate significant income losses if the person is either unemployed or out of the labor force.

The effects of policy instruments to support the poorer households do not overcome these households' negative income growth. Households with an unemployed member who likely receives unemployment benefits, and households receiving social assistance are significantly disadvantaged in the growth rates of equivalent income. Only the rent support payments are received by households which are not clearly below the average in growth rates. However, the coefficient is not significantly different from zero. Therefore we conclude that while government benefits do appear to reach those with the smallest household income growth, households of individuals who are only marginally integrated in the labor market suffer the most severe financial consequences following a health shock. 


\section{Summary and Conclusions}

The objective of this study was to evaluate the employment and earnings consequences of health shocks experienced by older German workers, based on the first eleven years of data in the German Socioeconomic Panel. The relevance of the question derives from several aspects. On the one hand we observe a decline in the labor force participation of older workers that frequently is related to health problems. This study finds that suffering a sudden and severe deterioration to one's health increases the risk of dropping out of employment and even more so of leaving the labor force altogether. There appears to be ample room for public policy initiatives to keep older workers in the labor force; possible measures are incentives for employers to accommodate health impaired workers or intensified use of medical rehabilitation programs (see Burkhauser, Butler and Kim, 1995).

In addition, this study addresses the financial consequences of health shocks. We find a small decline in individual earnings and in household equivalent income in the period following a health shock. Interestingly, those who subsequently suffer a health shock are already at the lower end of the income distribution before the health shock occurs. After a health shock the earnings of female employees decline more than those of their male counterparts, which is related to a larger probability of part-time employment. The household incomes of those who leave employment are most clearly affected by the health shock. The analysis compares the income and earnings dynamics for the population with and without health shocks over five periods surrounding the health shock.

To determine which subgroup of individuals suffers the largest earnings and income declines following a health shock, multivariate analyses of earnings and household income growth rates are performed. The health shock consequences for individual earnings growth is evaluated based on a selectivity corrected earnings regression: We cannot confirm that those with the highest incomes before the health shock will be the ones who suffer the least from it. Instead it is the remaining earnings potential in the form of young age, good health and long hours worked which is associated with the net effects of a health shock on earnings growth. 
While the effects of health shocks on labor earnings could be evaluated only for those who remained in the labor force, the growth rates in household equivalent income measure economic well-being for the full sample. The change in household income was regressed on controls for the individuals' earnings potential, for the structure of the household, as well as on indicators of government benefit receipt. The positive effects of the health-shocked individuals' remaining earnings capacity hold for the household income situation as well as for individual earnings. As one would expect, households with a larger number of labor force participants are less likely to suffer a decline in equivalent incomes in consequence of a health shock.

The policy instruments of the welfare state are significant factors in explaining household incomes. Their negative regression coefficients indicate that they are indeed provided to those most in need of support. The significant negative effects of the unemployment or out of the labor force status of the health-shocked individual on the income situation of the household indicates that those who are not or only marginally integrated in the labor market suffer the most severe financial consequences after a health shock. This confirms the hypothesis derived from the description of the German welfare state above. Therefore, health shocks not only are more likely to affect the population groups at the bottom of the earnings distribution, they also leave those with the most severe health impairments worst off. Government benefits appear to be targeted to this subgroup but based on this analysis they do not fully balance and insure against the negative consequences of the loss in earnings capacity for household incomes. This suggests that further cuts in the welfare state might punish the most needy. 
Endnotes

1. Out of all men aged 60 in 1991 about 26.9 percent had already retired due to disability (Riphahn, 1997). Of the unemployed in the age group 55-60 44 percent report health limitations (Bundesminister, 1996).

2. As examples see Westcott et al. (1985), Elkeles and Seifert (1993) or Arrow (1994).

3. As examples see Wagner (1991), Börsch-Supan (1992), Siddiqui (1997) or Schmidt (1995).

4. For further detail see Smith and Lin (1994) or Bundesminister (1995).

5. This sampling frame is very similar to Daly and Bound (1995). They investigate the employment situation of individuals who were employed at the onset of a health impairment.

6. By this condition individuals with low initial health satisfaction cannot experience a health shock. This censoring mechanism affects 14.5 percent of the observations which remain in the analysis sample.

7. This confirms the findings of Landua (1993) who points out that a person's response behavior is affected by the annual repetition of the survey. He concludes that the quality of answers improves over repeated surveys.

8. The only imputation mechanism for missing observations on the variables bigfirm, construct, electric, jobtrain, manager, manufact, office, public sect., retail, smallfirm, and unskilled was to set them to their preperiod value if the individual indicated that the employment situation had not changed. Similarly, the variables schooling and chronic were assigned preperiod values if current period information was missing.

9. In preliminary estimations the effects of working in the chemical, mechanical engineering, iron and steel, and the restaurant industry were tested. Since these industry effects did not appear to be very influential they were omitted in the final specification for the sake of parsimony.

10. The weights for household members are: Head of household 1, other members aged 0-6: $0.45,7-11: 0.65,12-15: 0.75,16-21: 0.9$, older than 21: 0.8 . These were in effect 1971 through 1990.

11. Table 7 reports on relative earnings with varying sample sizes over time, because some of the observations in early periods have no earnings observations in later years.

12. The measurement of longer run effects of health shocks depends very much on the definition of the sample. When only individuals are considered who report a labor income over all five periods, health shock effects cannot be observed. This is due to the selection of the more healthy individuals into continuous long-term employment. Unless otherwise stated the descriptive statistics are based on the subsample of observations who were employed and reported a wage and a household income in period $\mathrm{t}-1$.

13. This effect is robust to conditioning on full-time employment status in $t$ and $t+1$. 
14. The identifying variables omitted from the earnings equation are jointly and separately highly significant. An overidentification test showed that they would neither separately nor jointly add to the explanatory power of the earnings growth equation. 


\section{References}

Arrow, O.J., (1994), The Influence of Health on Unemployment in Germany: A Duration Model, DIW Vierteljahreshefte zur Wirtschaftsforschung 1/2 94, 133-138.

Baldwin, M.L., L.A. Zeager, and P.R. Flacco, (1994), Gender Differences in Wage Losses from Impairments, Journal of Human Resources 29(3), 865-887.

Berhold, Norbert and Rainer Fehn, (1997), Reforming the Welfare State: The German Case, in: Giersch, H. (ed.), Reforming the Welfare State, Berlin, 165-206.

Booth, Alison L., Carlos Garcia-Serrano, and Stephen P. Jenkins, (1996), New Men and New Women: Is there Convergence in Patterns of Labour Market Transition?, University of Essex - Programme on Labour Market Dynamics in a Changing Environment, Discussion Paper 96/01.

Börsch-Supan, A., (1992), Population Aging, Social Security Design and Early Retirement, Journal of Institutional and Theoretical Economics 148, 533-558.

Buhmann, B., L. Rainwater, G. Schmaus, T. M. Smeeding, (1988), Equivalence Scales, Well-Being, Inequality, and Poverty: Estimates Across Ten Countries Using the Luxembourg Income Study (LIS) Database, The Review of Income and Wealth 34(2), 115-142.

Bundesministerium für Arbeit und Sozialordnung, (1995), Übersicht über das Sozialrecht, Bonn, 3rd ed.

Bundesminister für Arbeit und Sozialordnung, (1996), Arbeits- und Sozialstatistik - Hauptergebnisse 1996, Bonn.

Burkhauser, Richard V. and Mary C. Daly, (1994), The Economic Consequences of Disability - A Comparison of German and American People with Disabilities, Journal of Disability Policy Studies 5(1), 25-52.

Burkhauser, Richard V. and Mary C. Daly, (1995), Employment and Economic Well-Being Following the Onset of a Disability: The Role for Public Policy, mimeo, Center for Policy Research, Syracuse University.

Burkhauser, Richard V., J.S. Butler, and Yang Woo Kim, (1995), The Importance of Employer Accommodation on the Job Duration of Workers with Disablities: A Hazard Model Approach, Labour Economics 2/95, 109-130.

Daly, Mary C. and John Bound, (1995), Worker Adaptation and Employer Accommodation Following the Onset of a Health Impairment, NBER Working Paper No. 5169, July 1995.

Dilnot, Andrew, (1995), The Assessment: The Future of the Welfare State, Oxford Review of Economic Policy 11(3), 1-10.

Elkeles, T. and W. Seifert, (1993), Unemployment and Health Impairments: Longitudinal Analyses for the Federal Republic of Germany, European Journal of Public Health 3/93, 28-37.

Even, William E. and David A. MacPherson, (1996), Employer Size and Labor Turnover: The Role of Pensions, Industrial and Labor Relations Review 49(4), 707-28.

Ferraro, Kenneth F., (1980), Self-Ratings of Health Among the Old and the Old-Old, Journal of Health and Social Behavior 21, 377-383.

Groothuis, Peter A., (1994), Turnover: The Implications of Establishment Size and Unionization, Quarterly Journal of Business and Economics 33(2), 41-53.

Haveman, R. and B. Wolfe, (1990), The Economic Well-Being of the Disabled 1962-1984, Journal of Human Resources 25(1), 32-54.

Landua, Detlef, (1993), Die Auswirkungen von Panelstudien auf die Antwortmuster von Zufriedenheitsangaben, DIW Discussion Papers No. 67, Berlin.

LaRue, Asenath, Lew Bank, Lissy Jarvik, and Monte Hetland, (1979), Health in Old Age: How Physicians' Ratings and Self-Ratings Compare?, Journal of Gerontology 34(5), 687-691.

Maddox, G. and E. Douglas, (1973), Self-Assessment of Health: A Longitudinal Study of Elderly Subjects, Journal of Health and Social Behavior 14(1), 87-93.

Morgan, Philip (ed.) (1995), Privatization and the Welfare State: Implications for Consumers and the Workforce, Aldershot, U.K.

Mossey, Jana M. and Evelyn Shapiro, (1982), Self-Rated Health: A Predictor of Mortality Among the Elderly, American Journal of Public Health 72(8), 800-808. 
Nagi, Saad , (1969), Congruency in Medical and Self-Assessment of Disability, Industrial Medicine, 2736.

Orszag, J. Michael and Dennis J. Snower, (1997), Expanding the Welfare System: A Proposal for Reform, CEPR Discussion Paper No. 1674.

Riphahn, Regina T., (1997), Disability Retirement and Unemployment - Substitute Pathways for Labor Force Exit ? Applied Economics 29, 551-561.

Sammartino, Frank J., (1987), The Effect of Health on Retirement, Social Security Bulletin 50(2), 31-47.

Schmidt, Peter, (1995), Die Wahl des Rentenalters: Theoretische und empirische Analyse des Rentenzugangsverhaltens in West- und Ostdeutschland, Peter Lang.

Siddiqui, Sikandar, (1997), The Pension Incentive to Retire: Empirical Evidence for West Germany, Journal of Population Economics 10(4), 463-486.

Sinn, Hans-Werner, (1995), A Theory of the Welfare State, Scandinavian Journal of Economics 97(4), 495-526.

Smith, Owen E. and Hsueh-Fang Lin, (1994), Social Policy, in: Smith, Owen E., The German Economy, Routledge, New York.

Steiner, Viktor, 1997, Extended Benefit-Entitlement Periods and the Duration of Unemployment in West Germany, ZEW Discussion Paper 97-14, Mannheim.

Wagner, Gert G., (1991), Altersgrenze, Arbeitsmarkt und Altersaustritt, Unpublished Manuscript, Technical University Berlin.

Westcott, G., P.-G. Svensson, H.F.K. Zöllner, (1985), Health Policy Implications of Unemployment, Copenhagen, World Health Organization. 
Figure 1: Distribution of Changes in Health Satisfaction by Sex

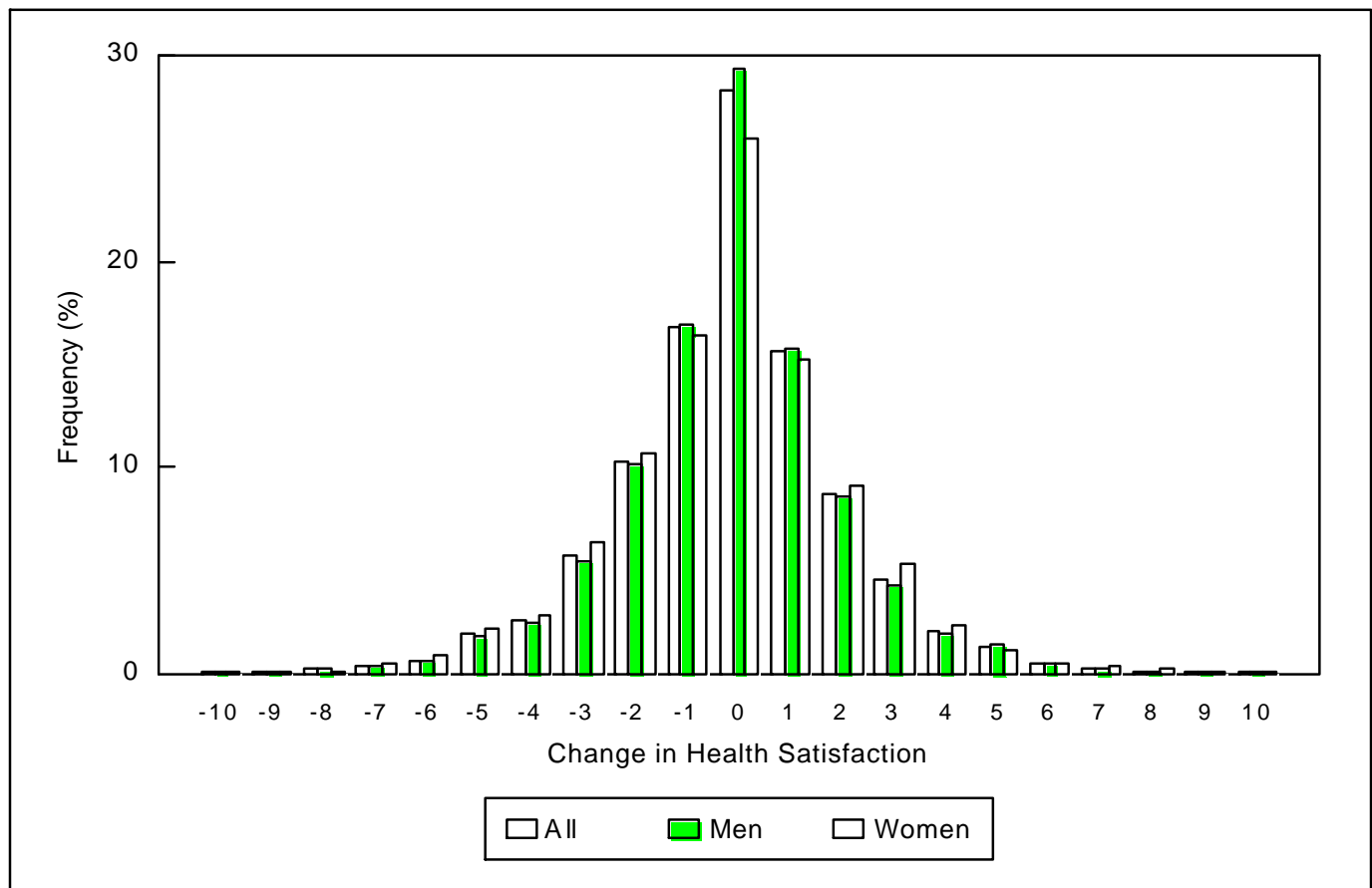

Source: $\quad$ Author's calculations based on GSOEP (1984-1994) 
Table 1: Correlation of Health Shock With Other Health Measures

\begin{tabular}{|c|c|c|c|c|}
\hline & $\begin{array}{l}\text { Sam } \\
\text { without } \\
\text { a Healtl }\end{array}$ & $\begin{array}{l}\text { with } \\
\text { ck }\end{array}$ & Factor $^{c}$ & Observation Years \\
\hline \multicolumn{5}{|l|}{ Period to Period: ${ }^{\mathrm{a}}$} \\
\hline New health limitation & $16.2 \%$ & $45.1 \%$ & 2.78 & $84-87,92$ \\
\hline New handicap & $2.6 \%$ & $5.4 \%$ & 2.06 & not: 90,93 \\
\hline New chronic disease & $10.9 \%$ & $25.4 \%$ & 2.34 & $84-89,91$ \\
\hline Health deterioration $^{\mathrm{b}}$ & $29.7 \%$ & $80.7 \%$ & 2.72 & 92,94 \\
\hline \multicolumn{5}{|l|}{ Last Year: } \\
\hline Any sickleave & $60.9 \%$ & $71.4 \%$ & 1.17 & $85-89,91,92,94$ \\
\hline Any sickleave $>6$ weeks & $5.0 \%$ & $14.9 \%$ & 3.01 & $85-89,91,92,94$ \\
\hline Average days of sickleave & 12.9 & 29.3 & 2.27 & $85-89,91,92,94$ \\
\hline Any hospital visit & $10.0 \%$ & $22.9 \%$ & 2.30 & not: 90,93 \\
\hline Average hospital visits & 1.5 & 2.2 & 1.49 & not: 90,93 \\
\hline Average nights in hospital & 21.2 & 30.0 & 1.42 & not: 90,93 \\
\hline Medical care after work accident & $4.1 \%$ & $7.4 \%$ & 1.80 & $87,88,90,91,94$ \\
\hline \multicolumn{5}{|l|}{ Last Three Months: } \\
\hline Any Doctor Visit & $68.7 \%$ & $83.5 \%$ & 1.22 & not: 90,93 \\
\hline
\end{tabular}

Note: (a) These measures are coded based on a comparison of responses in subsequent periods; e.g. a person is coded to suffer from a 'new health limitation' if he indicated no limitation in year $\mathrm{t}-1$ but a limitation in year t.

(b) This row relates the change in a categorical health status measure between 1992 and 1994 to a measure of a health shock that was defined across the same two-year period.

(c) This column describes how much more likely individuals who suffered a health shock are to report an indicator of deteriorated or poor health in comparison to the population that did not experience a health shock.

Source: Author's calculations based on GSOEP (1984-1994). 
Table 2: $\quad$ Distribution of Individual Transitions from Fulltime Employment in Period t-1 (in percent)

\begin{tabular}{|c|c|c|c|c|c|c|}
\hline \multirow[t]{2}{*}{ Transition into } & \multicolumn{3}{|c|}{ Full Sample } & \multicolumn{3}{|c|}{ Individuals who Experienced a Shock } \\
\hline & $\begin{array}{r}\text { First Year } \\
(\mathrm{t})\end{array}$ & $\begin{array}{r}\text { Second Year } \\
(t+1)\end{array}$ & $\begin{array}{r}\text { Third Year } \\
(t+2)\end{array}$ & $\begin{array}{r}\text { First Year } \\
(\mathbf{t})\end{array}$ & $\begin{array}{r}\text { Second Year } \\
(t+1)\end{array}$ & $\begin{array}{r}\text { Third Year } \\
(t+2)\end{array}$ \\
\hline Fulltime & 94.72 & 92.21 & 89.77 & 87.17 & 82.52 & 78.90 \\
\hline Parttime & 1.39 & 1.49 & 1.59 & 2.33 & 1.55 & 3.56 \\
\hline Unemployment & 2.26 & 3.34 & 4.29 & 5.00 & 6.60 & 7.12 \\
\hline OLF & 1.63 & 2.96 & 4.35 & 5.50 & 9.32 & 10.41 \\
\hline Total & 100.00 & 100.00 & 100.00 & 100.00 & 100.00 & 100.00 \\
\hline Number of obs. & 19,509 & 16,676 & 12,516 & 600 & 515 & 365 \\
\hline
\end{tabular}

Note: Reported distribution of labor force status in second and third year are not conditional on remaining in the labor force in the first year.

Source: Author's calculations based on GSOEP (1984-1994).

Table 3: Distribution Across States in the First Year after a Health Shock (period t) by Sex, Nationality, and Age (in percent)

\begin{tabular}{l|rr|rr|rrrr}
\hline Transition into & \multicolumn{1}{|c|}{ Men } & Women & Germans & Foreigners & $\mathbf{4 0 - 4 4}$ & $\mathbf{4 5 - 4 9}$ & $\mathbf{5 0 - 5 4}$ & $\mathbf{5 5 - 5 9}$ \\
\hline Fulltime & 90.21 & 79.53 & 88.17 & 85.88 & 91.03 & 88.89 & 85.11 & 82.11 \\
Parttime & 0.70 & 6.43 & 2.07 & 2.67 & 1.92 & 2.22 & 4.96 & 0.00 \\
Unemployment & 4.43 & 6.43 & 4.44 & 5.73 & 5.13 & 4.44 & 2.13 & 8.94 \\
OLF & 4.67 & 7.60 & 5.33 & 5.73 & 1.92 & 4.45 & 7.80 & 8.95 \\
\hline Total & 100.00 & 100.00 & 100.00 & 100.00 & 100.00 & 100.00 & 100.00 & 100.00 \\
Number of obs. & 429 & 171 & 338 & 262 & 156 & 180 & 141 & 123 \\
\hline
\end{tabular}

Source: Author's calculations based on GSOEP (1984-1994). 
Table 4: Definition of Variables and Descriptive Statistics

\begin{tabular}{|c|c|c|c|c|c|}
\hline \multirow[t]{2}{*}{ Variable } & \multirow[t]{2}{*}{ Definition } & \multicolumn{2}{|c|}{ Full Sample } & \multicolumn{2}{|c|}{ Health Shock } \\
\hline & & Mean & Std. D. & Mean & Std \\
\hline AGE & Age of the individual & 48.776 & 5.435 & 48.938 & 5.407 \\
\hline AGE2 & Age of the individual squared $\left(* 10^{-2}\right)$ & 24.086 & 5.347 & 24.241 & 5.340 \\
\hline AGG_UNEMP. & Aggregate national annual unemployment rate & 8.164 & 1.040 & 8.343 & .979 \\
\hline BIGFIRM & 1 if employed in firm with more than 2,000 employees, else 0 & .302 & .459 & .255 & .436 \\
\hline CHRONIC & 1 if individual has a chronic disease, else 0 & .274 & .446 & .270 & .444 \\
\hline CONSTRUCT & 1 if employed in construction (or related) industry, else 0 & .085 & .279 & .108 & .311 \\
\hline ELECTRIC & 1 if employed in electrical \& precision engineering industry, & .059 & .236 & .063 & .244 \\
\hline EXPERIENCE & Years of work experience $(=$ age -6 - schooling) & 31.717 & 6.196 & 32.532 & 6.039 \\
\hline EXPERIENCE2 & Years of work experience squared $\left(* 10^{-2}\right)$ & 10.444 & 3.942 & 10.947 & 3.94 \\
\hline FEMALE & 1 if female, else 0 & .243 & .429 & .285 & .452 \\
\hline FOREIGN & 1 if not of German nationality, else 0 & .319 & .466 & .437 & .496 \\
\hline JOBTRAIN & $\begin{array}{l}\text { Categorical indicator for level of training required for job } \\
\text { 2=Briefly, } 3=\text { Learning on the Job, } 4=\text { Courses, } \\
6=\text { Polytechnical University Degree, } 7=\text { University Degree ) }\end{array}$ & 3.879 & 1.642 & 3.345 & 1.639 \\
\hline LR_INCOME & Log of real net monthly income & 7.896 & .431 & 7.799 & .405 \\
\hline MANAGER & 1 if white collar worker in highly qualified or leading position, & .104 & .305 & .052 & .221 \\
\hline MANUFACT & 1 if occupation in production or related industry, else 0 & .477 & .499 & .582 & .494 \\
\hline MARRIED & 1 if married, else 0 & .827 & .379 & .803 & .398 \\
\hline MARR*FEM & 1 if married and female, else 0 & .167 & .373 & .203 & .403 \\
\hline OFFICE & 1 if occupation as office worker or related, else 0 & .156 & .363 & .107 & $.30 s$ \\
\hline PUBLIC SECT. & 1 if employed in publice sector, else 0 & .230 & .420 & .178 & .383 \\
\hline PR_INCOME & Predicted real net monthly income $\left(* 10^{-3}\right)$ & 2.833 & .937 & 2.542 & .760 \\
\hline RETAIL & 1 if employed in retailing industry, else 0 & .039 & .195 & .035 & .184 \\
\hline SCHOOLING & Years of schooling & 11.058 & 2.580 & 10.407 & 2.332 \\
\hline SHOCK & 1 if experienced a health shock, else 0 & .031 & .173 & 1.000 & .000 \\
\hline SMALLFIRM & 1 if employed in firm with less than 20 employees, else 0 & .153 & .340 & .155 & .362 \\
\hline UNSKILLED & 1 if blue collar worker without apprenticeship, else 0 & .791 & .407 & .768 & .422 \\
\hline
\end{tabular}


Table 5: $\quad$ Coefficient Estimates for Transitions from Fulltime Employment into:

\begin{tabular}{|c|c|c|c|c|c|c|}
\hline \multirow[t]{2}{*}{ Variable } & \multicolumn{2}{|c|}{ Part-Time Empl. } & \multicolumn{2}{|c|}{ Unemployment } & \multicolumn{2}{|c|}{ Out of the Labor Force } \\
\hline & Coeff. & Std. Dev. & Coeff. & Std. Dev. & Coeff. & Std. Dev. \\
\hline AGE & -.179 & .221 & -.683 & **. .165 & -1.047 & $* * .195$ \\
\hline AGE2 & .157 & .227 & .737 & $* * .166$ & 1.144 & **.194 \\
\hline FOREIGN & -.258 & .172 & .342 & $* * .120$ & -.166 & .143 \\
\hline FEMALE & 2.350 & $* * .535$ & .498 & .261 & -.363 & .346 \\
\hline MARRIED & .342 & .477 & -.420 & $* * .159$ & -.153 & .204 \\
\hline MARRFEM & .448 & .509 & .434 & .251 & .804 & $* * .309$ \\
\hline PR_INCOME & -.022 & .253 & .479 & $* * .176$ & -.587 & $* .263$ \\
\hline SCHOOLING & .125 & $* * .042$ & -.080 & $* .037$ & .049 & .047 \\
\hline JOBTRAIN & -.170 & $* * .064$ & -.250 & $* * .052$ & -.075 & .063 \\
\hline CHRONIC & .059 & .144 & .630 & $* * .102$ & .509 & $* * .119$ \\
\hline SHOCK & .595 & $* .292$ & .759 & $* * .200$ & 1.267 & $* * .196$ \\
\hline BIGFIRM & -.388 & $* .186$ & -.265 & $* .133$ & .111 & .149 \\
\hline SMALLFIRM & .668 & $* * .172$ & .602 & $* * .137$ & .089 & .173 \\
\hline OFFICE & -.444 & $* .182$ & -.074 & .200 & -.641 & $* * .211$ \\
\hline MANUFACT & -.450 & *.192 & .433 & $* * .140$ & -.155 & .154 \\
\hline CONSTRUCT & .244 & .386 & .292 & .157 & .418 & $* .198$ \\
\hline RETAIL & .557 & $* * .216$ & -.210 & .278 & .096 & .278 \\
\hline ELECTRIC & -.878 & $* .402$ & -.526 & $* .232$ & -.360 & .291 \\
\hline PUBLIC SECT & .363 & $* .169$ & -1.009 & **.199 & -.360 & .291 \\
\hline AGG_UNEMPL. & .143 & .294 & .578 & **.199 & -.116 & .262 \\
\hline CONSTANT & -2.839 & 5.980 & 7.300 & 4.431 & 21.539 & *5.392 \\
\hline $\mathrm{N}=19509$ & $\mathrm{LL}=-$ & & $*=$ signif & at $5 \%$ & $* *=\operatorname{signi}$ & t at $1 \%$ \\
\hline
\end{tabular}

Note: The estimation controls for two sets of regional and period fixed effects.

Source: Author's calculations based on GSOEP (1984-1994). 
Table 6: $\quad$ Simulation Results

\begin{tabular}{|c|c|c|c|c|c|c|c|c|c|c|c|c|}
\hline \multirow[t]{3}{*}{ Variable } & \multicolumn{12}{|c|}{ Transition into } \\
\hline & \multicolumn{3}{|c|}{ Fulltime Empl. } & \multicolumn{3}{|c|}{ Parttime Empl. } & \multicolumn{3}{|c|}{ Unemployment } & \multicolumn{3}{|c|}{ Out of Labor Force } \\
\hline & (1) & (2) & D & (1) & (2) & D & (1) & (2) & D & (1) & (2) & D \\
\hline Sample Averag. & 94.72 & & & 1.39 & & & 2.26 & & & 1.63 & & \\
\hline AGE & 95.64 & 94.25 & -1.39 & 1.60 & 1.19 & -0.41 & 1.81 & 2.60 & 0.79 & 0.95 & 1.96 & 1.01 \\
\hline FEMALE & 96.25 & 89.58 & -6.67 & 0.32 & 4.51 & 4.19 & 1.88 & 3.99 & 2.11 & 1.55 & 1.92 & 0.36 \\
\hline FOREIGN & 94.81 & 94.64 & -0.17 & 1.51 & 1.18 & -0.33 & 1.94 & 2.72 & 0.77 & 1.74 & 1.47 & -0.27 \\
\hline MARRIED & 94.74 & 94.50 & -0.24 & 0.85 & 1.63 & 0.79 & 2.88 & 2.16 & -0.72 & 1.53 & 1.71 & 0.18 \\
\hline PR_INCOME & 94.35 & 93.55 & -0.80 & 1.40 & 1.32 & -0.08 & 1.85 & 4.34 & 2.48 & 2.40 & 0.79 & -1.61 \\
\hline SCHOOLING & 94.82 & 94.43 & -0.39 & 1.06 & 1.93 & 0.87 & 2.62 & 1.73 & -0.89 & 1.50 & 1.91 & 0.41 \\
\hline CHRONIC & 95.37 & 93.07 & -2.31 & 1.39 & 1.42 & 0.03 & 1.86 & 3.33 & 1.47 & 1.38 & 2.19 & 0.81 \\
\hline SHOCK & 94.93 & 88.93 & -6.00 & 1.37 & 2.19 & 0.82 & 2.18 & 4.16 & 1.97 & 1.52 & 4.73 & 3.21 \\
\hline BIGFIRM & 94.53 & 95.31 & 0.78 & 1.50 & 1.04 & -0.45 & 2.39 & 1.86 & -0.53 & 1.58 & 1.79 & 0.21 \\
\hline SMALLFIRM & 95.18 & 92.63 & -2.55 & 1.19 & 2.17 & 0.98 & 2.02 & 3.52 & 1.50 & 1.62 & 1.69 & 0.07 \\
\hline OFFICE & 94.46 & 95.87 & 1.41 & 1.51 & 1.01 & -0.50 & 2.26 & 2.15 & -0.11 & 1.76 & 0.96 & -0.80 \\
\hline MANUFACT & 94.91 & 94.79 & -0.12 & 1.57 & 1.02 & -0.55 & 1.75 & 2.67 & 0.93 & 1.78 & 1.52 & -0.26 \\
\hline CONSTRUCT & 94.86 & 93.17 & -1.68 & 1.39 & 1.70 & 0.31 & 2.18 & 2.83 & 0.64 & 1.57 & 2.29 & 0.72 \\
\hline RETAIL & 94.78 & 94.18 & -0.60 & 1.32 & 2.22 & 0.90 & 2.28 & 1.83 & -0.44 & 1.62 & 1.77 & 0.14 \\
\hline ELECTR & 94.58 & 96.72 & 2.14 & 1.44 & 0.64 & -0.80 & 2.32 & 1.43 & -0.89 & 1.66 & 1.21 & -0.44 \\
\hline PUBLIC SEC. & 94.50 & 95.88 & 1.38 & 1.27 & 1.82 & 0.55 & 2.53 & 0.95 & -1.57 & 1.71 & 1.34 & -0.36 \\
\hline AGG_UNEMP. & 95.53 & 92.82 & -2.71 & 1.23 & 1.58 & 0.34 & 1.35 & 4.19 & 2.84 & 1.88 & 1.41 & -0.47 \\
\hline
\end{tabular}

Note: - Columns labelled (1) present the average predicted probability after setting (i) dichotomous variables to 0 (ii) continuous variables (AGE, PR_INCOME, SCHOOLING, and AGG_UNEMP.) to one standard deviation below the mean

Columns labelled (2) present the average predicted probability after setting (i) dichotomous variables to 1 (ii) continuous variables (AGE, PR_INCOME, SCHOOLING, and AGG_UNEMP.) to one standard deviation above the mean.

Columns labelled D present the absolute difference between columns (1) and (2).

- Deviations between probability differences and column $D$ are due to rounding errors. 
Table 7: Relative Income Position of Individuals Suffering a Health Shock

(a) Full Sample

\begin{tabular}{lccc}
\hline & Earnings & Hh. Income 1 & Hh. Income 2 \\
\hline $\mathbf{t}-\mathbf{1}$ & 0.883 & 0.943 & 0.925 \\
$\mathbf{t}$ & 0.876 & 0.923 & 0.917 \\
$\mathbf{t}+\mathbf{1}$ & $\mathbf{0 . 8 7 2}$ & $\mathbf{0 . 8 9 6}$ & $\mathbf{0 . 8 9 0}$ \\
$\mathbf{t}+\mathbf{2}$ & 0.876 & 0.902 & 0.914 \\
$\mathbf{t}+\mathbf{3}$ & 0.882 & 0.892 & 0.901 \\
\hline
\end{tabular}

(b) Earnings by Subsample ${ }^{c}$

\begin{tabular}{lcccccc}
\hline & $\begin{array}{c}\text { German } \\
\text { Men(196) }\end{array}$ & $\begin{array}{c}\text { German } \\
\text { Women (67) }\end{array}$ & $\begin{array}{c}\text { Foreign } \\
\text { Men (138) }\end{array}$ & $\begin{array}{c}\text { Foreign } \\
\text { Women (65) }\end{array}$ & $\begin{array}{c}\text { Fulltime } \\
\mathbf{( 4 5 5 )}\end{array}$ & $\begin{array}{c}\text { Parttime } \\
(\mathbf{1 1})\end{array}$ \\
\hline $\mathbf{t}-\mathbf{1}$ & 0.891 & 0.935 & 0.976 & 0.963 & 0.889 & 0.842 \\
$\mathbf{t}$ & 0.884 & 0.941 & 0.972 & 0.928 & 0.881 & 0.794 \\
$\mathbf{t}+\mathbf{1}$ & 0.895 & 0.937 & & 0.905 & 0.880 & 0.837 \\
$\mathbf{t}+\mathbf{2}$ & 0.920 & 0.908 & 0.964 & 0.913 & 0.886 & 0.847 \\
$\mathbf{t}+\mathbf{3}$ & 0.937 & 0.892 & 0.977 & 0.957 & 0.889 & 0.904 \\
\hline
\end{tabular}

(c) Household Income by Nationality and Employment Status in Periods "t" and "t+1" c

\section{German (295) Foreign (243)}

Hh. Income $1 \quad$ Hh. Income 2 Hh. Income $1 \quad$ Hh. Income 2

\begin{tabular}{lllll}
\hline $\mathbf{t}-\mathbf{1}$ & 0.950 & 0.914 & 1.025 & 0.993 \\
$\mathbf{t}$ & 0.949 & 0.914 & 0.979 & 0.975 \\
$\mathbf{t}+\mathbf{1}$ & $\mathbf{0 . 8 9 7}$ & $\mathbf{0 . 8 7 0}$ & 0.981 & $\mathbf{0 . 9 7 0}$ \\
$\mathbf{t}+\mathbf{2}$ & 0.924 & 0.903 & 0.949 & 0.983 \\
$\mathbf{t}+\mathbf{3}$ & 0.922 & 0.885 & 0.931 & 0.980 \\
\hline
\end{tabular}

Fulltime (473)

Unemployed (26)

Out of the Labor Force (28)

Hh. Income 1 Hh. Income 2 Hh. Income 2

Hh. Income 1 Hh. Income 2

\begin{tabular}{lllllll}
\hline $\mathbf{t}-\mathbf{1}$ & $0.945(0.931)^{\mathrm{d}}$ & $0.927(0.931)$ & $0.955(1.031)$ & $1.010(1.003)$ & $0.901(0.969)$ & $0.890(0.951)$ \\
$\mathbf{t}$ & $0.941(0.935)$ & $0.934(0.931)$ & $0.941(1.016)$ & $1.004(0.975)$ & $0.813(0.932)$ & $0.793(0.937)$ \\
$\mathbf{t}+\mathbf{1}$ & $0.904(0.913)$ & $0.900(0.916)$ & $0.997(0.984)$ & $0.986(0.909)$ & $0.935(0.956)$ & $0.944(0.977)$ \\
$\mathbf{t}+\mathbf{2}$ & $0.906(0.938)$ & $0.925(0.921)$ & $0.962(0.901)$ & $0.951(0.927)$ & $1.017(0.914)$ & $1.013(0.949)$ \\
$\mathbf{t}+\mathbf{3}$ & $0.893(0.914)$ & $0.912(0.905)$ & $1.266(0.940)$ & $1.098(0.952)$ & $0.944(0.912)$ & $0.958(0.920)$
\end{tabular}

Note: (a) The period indicator $t$ represents the period by which the health shock has occurred. Income comparisons are presented for the periods prior to the shock ( $t-1)$, of the shock $(t)$, and subsequent periods $(t+1, t+2, t+3)$.

(b) Household Income type 1 is generated using the welfare system equivalence scale, type 2 was obtained after dividing by the square root of the number of household members.

(c) Number of health shocked individuals in the relevant subsample in period t in parentheses.

(d) Figures in parentheses describe subsamples in given employment category in period $t+1$.

Source: Author's calculations based on GSOEP (1984-1994). 
Table 8: Income Changes for Individuals Suffering a Health Shock

(a) Full Sample

\begin{tabular}{lcc}
\hline & Earnings & Hh. Income \\
\hline $\mathrm{t} / \mathrm{t}-1$ & 1.056 & 1.048 \\
& $(1.039)$ & $(1.074)$ \\
$\mathrm{t}+1 / \mathrm{t}-1$ & $\mathbf{1 . 0 3 8}$ & 1.040 \\
& $(1.057)$ & $(1.092)$ \\
$\mathrm{t}+2 / \mathrm{t}-1$ & 1.053 & 1.080 \\
& $(1.071)$ & $(1.114)$ \\
$\mathrm{t}+3 / \mathrm{t}-1$ & 1.092 & 1.092 \\
& $(1.090)$ & $(1.129)$ \\
\hline
\end{tabular}

(b) Earnings by Subsample and Employment Status in Period "t" d

\begin{tabular}{lcccccc}
\hline & $\begin{array}{c}\text { German } \\
\text { Men (196) }\end{array}$ & $\begin{array}{c}\text { German } \\
\text { Women (67) }\end{array}$ & $\begin{array}{c}\text { Foreign } \\
\text { Men (138) }\end{array}$ & $\begin{array}{c}\text { Foreign } \\
\text { Women (65) }\end{array}$ & $\begin{array}{c}\text { Fulltime } \\
(\mathbf{4 5 5})\end{array}$ & $\begin{array}{c}\text { Parttime } \\
(\mathbf{1 1})\end{array}$ \\
\hline $\mathrm{t} / \mathrm{t}-1$ & 1.046 & 1.010 & 1.137 & 0.956 & 1.061 & 0.828 \\
& $(1.042)$ & $(1.042)$ & $(1.027)$ & $(1.054)$ & $(1.042)$ & $(0.895)$ \\
$\mathrm{t}+1 / \mathrm{t}-1$ & 1.068 & 1.019 & 1.038 & 0.967 & 1.041 & 0.930 \\
& $(1.061)$ & $(1.064)$ & $(1.045)$ & $(1.058)$ & $(1.059)$ & $(0.942)$ \\
$\mathrm{t}+2 / \mathrm{t}-1$ & 1.085 & 1.037 & 1.062 & 0.966 & 1.056 & 0.960 \\
& $(1.078)$ & $(1.073)$ & $(1.055)$ & $(1.069)$ & $(1.073)$ & $(0.952)$ \\
$\mathrm{t}+3 / \mathrm{t}-1$ & 1.126 & 1.120 & 1.069 & 1.024 & 1.098 & 0.987 \\
& $(1.104)$ & $(1.080)$ & $(1.073)$ & $(1.068)$ & $(1.091)$ & $(0.996)$ \\
\hline
\end{tabular}

(c) Houshold Income by Subsample and Employment Status in Period "t" d

\begin{tabular}{lcccccc}
\hline & $\begin{array}{c}\text { German } \\
\mathbf{( 2 9 5 )}\end{array}$ & $\begin{array}{c}\text { Foreign } \\
\mathbf{( 2 4 3 )}\end{array}$ & $\begin{array}{c}\text { Fulltime } \\
\mathbf{( 4 7 3 )}\end{array}$ & $\begin{array}{c}\text { Partime } \\
\mathbf{( 1 1 )}\end{array}$ & $\begin{array}{c}\text { Unemployed } \\
\mathbf{( 2 6 )}\end{array}$ & $\begin{array}{c}\text { OLF } \\
(\mathbf{2 8})\end{array}$ \\
\hline $\mathrm{t} / \mathrm{t}-1$ & 1.068 & 1.024 & 1.070 & 1.001 & 0.838 & 0.895 \\
& $(1.087)$ & $(1.046)$ & $(1.082)$ & $(1.084)$ & $(0.842)$ & $(0.897)$ \\
$\mathrm{t}+1 / \mathrm{t}-1$ & 1.046 & 1.032 & 1.050 & 1.055 & 0.908 & 0.991 \\
& $(1.104)$ & $(1.068)$ & $(1.100)$ & $(1.024)$ & $(0.930)$ & $(0.915)$ \\
$\mathrm{t}+2 / \mathrm{t}-1$ & 1.094 & 1.061 & 1.084 & 0.989 & 0.989 & 1.113 \\
& $(1.128)$ & $(1.083)$ & $(1.119)$ & $(1.042)$ & $(0.994)$ & $(0.981)$ \\
$\mathrm{t}+3 / \mathrm{t}-1$ & 1.106 & 1.074 & 1.091 & 1.189 & 1.029 & 1.126 \\
& $(1.142)$ & $(1.101)$ & $(1.134)$ & $(1.067)$ & $(1.051)$ & $(0.921)$ \\
\hline
\end{tabular}

Note: (a) Figures in parentheses present income changes for the sample not experiencing a health shock.

(b) The first column indicates over which time periods the income ratios are generated: e.g. the first ratio relates the income of the period in which the shock occurred to that of the period prior to the shock, the second ratio relates the income of the period following the shock to that of the period prior to the shock, and the last two rows relate incomes received in the later periods to the same base.

(c) Only one equivalence measures for household income is presented, since in most cases - except for those with changing household composition - the equivalence correction cancels out when calculating the changes in incomes.

(d) Size of sample with health shocked individuals in period $t$ in parentheses.

(e) Group average after dropping one outlier observation with a 1100 percent increase in income.

Source: Author's calculations based on GSOEP (1984-1994). 
Table 9: Development of Labor Earnings for Subsamples of Employed Individuals a

(a) Percentage Change from Period t-1 to Period $t+1$

\begin{tabular}{lccc}
\hline & Health Shock & No Health & Difference \\
\hline German Men (171) & 6.81 & 6.11 & 0.70 \\
German Women (55) & 1.90 & 6.37 & -4.47 \\
Foreign Men (117) & 3.83 & 4.47 & -0.64 \\
Foreign Women (60) & -3.26 & 5.79 & -9.05 \\
\hline
\end{tabular}

(b) Percentage Change from Period t-1 to Period t+2

\begin{tabular}{lccc}
\hline & Health Shock & No Health & Difference \\
\hline & 8.53 & 7.77 & Gernoan6Men \\
German Women (54) & 3.73 & 7.33 & -3.60 \\
Foreign Men (96) & 6.21 & 5.53 & 0.68 \\
Foreign Women (53) & -3.42 & 6.91 & -10.33 \\
\hline
\end{tabular}

(c) Percentage Change from Period t -1 to Period t+3

\begin{tabular}{lccc}
\hline & Health Shock & No Health & Difference \\
\hline German Men (111) & 12.63 & 10.36 & 2.27 \\
German Women (41) & 12.02 & 8.03 & 3.99 \\
Foreign Men (87) & 6.87 & 7.32 & -0.45 \\
Foreign Women (43) & 2.43 & 6.82 & -4.39 \\
\hline
\end{tabular}

Note: (a) Figures in parentheses provide number of observations with a health shock in the period under evaluation.

Source: $\quad$ Author's calculations based on GSOEP (1984-1994). 
Table 10: Distribution of Dependent Variables by Subsamples of Employed Individuals a (a) Percentage change in gross real earnings between period $\mathrm{t}-1$ and $\mathrm{t}+1$

\begin{tabular}{lccccc}
\hline Percentile: & 10th & 25th & 50th & 75th & 90th \\
\hline Full Sample (339) & -.199 & -.076 & .001 & .098 & .256 \\
\hdashline & -.154 & -.061 & .015 & .107 & $\begin{array}{l}\text { Germ:99 } \\
\text { Men (145) }\end{array}$ \\
& & & & & $.08 .$. \\
German Women (45) & -.134 & -.033 & .033 & .088 & .182 \\
Foreign Men (99) & -.251 & -.105 & -.015 & .121 & .292 \\
Foreign Women (50) & -.235 & -.144 & -.049 & .056 & .135 \\
\hdashline Top Earners in t-1 (142) & -.191 & -.070 & .003 & .064 & .170 \\
Bottom Earners in t-1 (192) & -.183 & -.085 & .000 & .149 & .327 \\
Top Earners in t+1 (142) & -.077 & -.019 & .037 & .130 & .303 \\
Bottom Earners in t+1 (197) & -.238 & -.133 & -.033 & .070 & .230 \\
\hline
\end{tabular}

(b) Percentage change in equivalent household income between period t-1 and t+1

\begin{tabular}{lccccc}
\hline Percentile: & 10th & 25th & 50th & 75th & 90th \\
\hline Full Sample (396) & -.312 & -.142 & -.086 & & .462 \\
\hdashline German Men (171) & -.285 & -.164 & -.015 & .189 & .399 \\
German Women (56) & -.329 & -.066 & .060 & .189 & .647 \\
Foreign Men (113) & -.331 & -.131 & .018 & .177 & .471 \\
Foreign Women (56) & -.328 & -.173 & .033 & .205 & .359 \\
\hdashline Fulltime Employed (355) & -.272 & -.115 & .023 & .211 & .515 \\
Parttime Employed (4) & -.174 & -.051 & .085 & .138 & .177 \\
Unemployed (13) & -.449 & -.286 & -.217 & -.093 & -.012 \\
Out of Labor Force (24) & -.446 & -.237 & -.069 & .006 & .232 \\
\hline
\end{tabular}

Note: (a) Both tables describe the samples used in the multivariate analysis: Observations with non missing household and income measures in the pre-health shock period (t-1), which experienced a health shock between $\mathrm{t}-1$ and $\mathrm{t}$, and was fulltime employed in $\mathrm{t}-1$. Panel (a) further conditions on fulltime employment in periods $t$ and $t+1$.

(b) Figures in parentheses are number of observations in subsamples.

Source: Author's calculations based on GSOEP (1984-1994). 
Table 11: Descriptive Statistics

\begin{tabular}{|c|c|c|c|}
\hline Variable & Definition & & Std. Dev. \\
\hline \multicolumn{4}{|c|}{ Individual Labor Earnings Change $(\mathrm{N}=339)$} \\
\hline DEPEND. VAR. & $\begin{array}{l}\text { Percentage change in real monthly labor earnings } \\
\text { between } t-1 \text { and } t+1\end{array}$ & .046 & .358 \\
\hline AGE & Age & 47.917 & 5.289 \\
\hline HEALTH SAT. & Health Satisfaction in period $t+1$ & 2.917 & 1.664 \\
\hline FEMALE & Indicator: Individual is female & .280 & .450 \\
\hline FOREIGN & Indicator: Individual is foreigner & .440 & .497 \\
\hline HOURS & Number of hours worked last week in $t+1$ & 29.272 & 20.304 \\
\hline SCHOOLING & Years of schooling & 10.420 & 2.375 \\
\hline TENURE & Years of tenure & 13.485 & 8.410 \\
\hline SMALLFIRM & $\begin{array}{l}\text { Indicator: Individual works in firm with less than } 20 \\
\text { employees }\end{array}$ & .106 & .309 \\
\hline BIGFIRM & $\begin{array}{l}\text { Indicator: Individual works in firm with more than } \\
2,000 \text { employees }\end{array}$ & .307 & .462 \\
\hline \multicolumn{4}{|c|}{ Selectivity Correction Probit $(\mathrm{N}=552)$} \\
\hline DEPEND.VAR. & Indicator: Individual fulltime employed in $\mathrm{t}+1$ & .688 & .464 \\
\hline AGEGROUP 1 & Indicator: Individual aged 40-44 & .274 & .446 \\
\hline AGEGROUP 2 & Indicator: Individual aged 45-49 & .297 & .457 \\
\hline AGEGROUP 3 & Indicator: Individual aged 50-54 & .226 & .419 \\
\hline TitrieArlend & & 1988.701 & 2.855 \\
\hline OFFICE & Indicator: Occupation as office worker & .107 & .309 \\
\hline MANUFAC & $\begin{array}{l}\text { Indicator: Occupation in producation or related } \\
\text { industry }\end{array}$ & .578 & .494 \\
\hline SCHOOLING & Years of schooling & 10.360 & 2.303 \\
\hline AGG_UNEMP & Aggregate national unemployment rate & 8.316 & .988 \\
\hline HEALTH SAT. & Health Satisfaction in period $t+1$ & 2.594 & 1.740 \\
\hline BIGFIRM & $\begin{array}{l}\text { Indicator: Individual works in firm with more than } \\
2,000 \text { employees }\end{array}$ & .275 & .447 \\
\hline SMALLFIRM & $\begin{array}{l}\text { Indicator: Individual works in firm with less than } 20 \\
\text { employees }\end{array}$ & .147 & .354 \\
\hline FEMALE & Indicator: Individual is female & .283 & .451 \\
\hline FOREIGN & Indicator: Individual is foreigner & .446 & .497 \\
\hline
\end{tabular}




\begin{tabular}{|c|c|c|c|}
\hline Variable & Definition & Mean & Std. Dev. \\
\hline \multicolumn{4}{|c|}{ Household Equivalent Income Change $(\mathrm{N}=396)$} \\
\hline DEPEND. VAR. & $\begin{array}{l}\text { Percentage change in real monthly household } \\
\text { equivalent incomes between } t-1 \text { and } t+1\end{array}$ & .062 & .381 \\
\hline FEMALE & Indicator: Individual is female & .283 & .451 \\
\hline \multirow[t]{2}{*}{ FOREIGN } & Indicator: Individual is foreigner & .427 & .495 \\
\hline & Indicator: Individual works parttime in $\mathrm{t}+1$ & .010 & $\begin{array}{l}\quad .100 \\
\text { PARTTI } \\
\text { ME }\end{array}$ \\
\hline UNEMPLOYED & Indicator: Individual unemployed in $\mathrm{t}+1$ & .033 & .178 \\
\hline OLF & Indicator: Individual out of the labor force in $\mathrm{t}+1$ & .061 & .239 \\
\hline NUMBER_FT & Number of fulltime earners in household & 1.634 & .746 \\
\hline NUMBER_PT & Number of parttime earners in household & .129 & .335 \\
\hline NUMBER_KIDS & Number of children under age 16 in household & .596 & 1.018 \\
\hline $\begin{array}{l}\text { SOCIAL } \\
\text { ASSIST. }\end{array}$ & Indicator: Household received social assistance in $\mathrm{t}$ & .025 & .157 \\
\hline RENT SUPPORT & Indicator: Household received rent support in $\mathrm{t}$ & .023 & .149 \\
\hline HEALTH SAT. & Health Satisfaction in period $t+1$ & 2.770 & 1.696 \\
\hline HOURS & Number of hours worked last week in $t+1$ & 28.861 & 20.266 \\
\hline TENURE & Years of tenure & 138.520 & 86.548 \\
\hline AGE & Age & 48.588 & 5.463 \\
\hline
\end{tabular}

Source: $\quad$ Author's calculations based on GSOEP (1984-1994). 
Table 12: Estimation Results: Change in Individual Labor Earnings

\begin{tabular}{|c|c|c|c|}
\hline Earnings Change & Coefficient & Standard Error & t - Ratio \\
\hline AGE & -.0087 & & -2.232 \\
\hline HEALTH SAT. & .0636 & .0124 & 5.125 \\
\hline FEMALE & -.0422 & .0469 & -.901 \\
\hline FOREIGN & -.0413 & .0460 & -.898 \\
\hline HOURS & .0014 & .0009 & 1.605 \\
\hline SCHOOLING & .0073 & .0097 & .755 \\
\hline TENURE & .0034 & .0018 & 1.837 \\
\hline SMALLFIRM & -.0481 & .0652 & -.738 \\
\hline BIGFIRM & .0354 & .0472 & .750 \\
\hline CONSTANT & -.0737 & .2322 & -.317 \\
\hline LAMBDA & -.8367 & .0448 & -18.657 \\
\hline \multicolumn{4}{|l|}{ PROBIT } \\
\hline AGEGROUP 1 & .4643 & .1492 & 3.113 \\
\hline AGEGROUP 2 & $.3079 *$ & .1204 & 2.557 \\
\hline AGEGROUP 3 & .0046 & .1122 & .041 \\
\hline YEAR & -.0551 & .0194 & -2.847 \\
\hline OFFICE & .1017 & .1523 & .668 \\
\hline MANUFAC & .0114 & .0889 & .129 \\
\hline SCHOOLING & -.0103 & .0257 & -.400 \\
\hline AGG_UNEMP & -.2461 & .0657 & -3.744 \\
\hline HEALTH SAT. & .1571 & .0308 & 5.098 \\
\hline BIGFIRM & .0918 & .1239 & .741 \\
\hline SMALLFIRM & -.3322 & .1552 & -2.140 \\
\hline FEMALE & -.1156 & .1264 & -.914 \\
\hline FOREIGN & -.0896 & .1186 & -.755 \\
\hline CONSTANT & 111.500 & 38.8326 & 2.871 \\
\hline \multicolumn{4}{|l|}{ Nog 55Relihood = -387.2767 } \\
\hline
\end{tabular}

Notes: (a) Variables as defined in Table 11.

(b) ** represents significance at the 1 percent level.

Source: $\quad$ Author's calculations based on GSOEP (1984-1994). 
Table 13: Estimation Results: Change in Equivalent Household Income

\begin{tabular}{l|cc|c|c}
\hline Income Change & Coefficient & Standard Error & t - Ratio \\
\hline FEMALE & .0761 & $*$ & .0443 & 1.720 \\
FOREIGN & -.0389 & & .0405 & -.959 \\
PARTTIME & -.0574 & & .1916 & -.300 \\
UNEMPLOYED & -.2481 & $* *$ & .1065 & -2.330 \\
OLF & -.1404 & $*$ & .0827 & -1.698 \\
NUMBER_FT & .0597 & $* *$ & .0265 & 2.252 \\
NUMBER_PT & .0986 & $*$ & .0585 & 1.685 \\
NUMBER_KIDS & .0382 & $*$ & .0211 & 1.815 \\
SOCIAL_ASSIST. & -.2461 & $* *$ & .1226 & -2.008 \\
RENT SUPPORT & .0800 & & .1349 & .593 \\
HEALTH SAT. & .0212 & $*$ & .0113 & 1.875 \\
HOURS & .0021 & $* *$ & .0010 & 2.200 \\
TENURE & .0001 & & .0002 & .438 \\
AGE & .0015 & & .0039 & .380 \\
CONSTANT & -.2591 & & .1929 & -1.343 \\
\hline Adj. R ${ }^{2}=0.054$ & $\mathrm{~N}=396$ & \\
\hline
\end{tabular}

Notes: (a) Variables as defined in Table 11.

(b) $*(* *)$ represents significance at the $10(5)$ percent level.

Source: $\quad$ Author's calculations based on GSOEP (1984-1994). 